\title{
Analisis Penggunaan Lahan pada Bentang Lahan Kipas Laharik Gunungapi Kelud melalui Sistem Informasi Geografis
}

\author{
Ardli Swardana ${ }^{*}$ \\ ${ }^{1}$ Program Studi Agroteknologi, Fakultas Pertanian, Universitas Garut \\ *Corresponding author: ardli@uniga.ac.id
}

\begin{abstract}
Abstrak
Indonesia merupakan negara yang mendapat sebutan ring of fire karena adanya deretan gunung api yang melewatinya. Disetiap aktivitasnya akan banyak menghasilkan banyak keragaman bentuk lahan. Tujuan penelitian ini adalah melakukan analisis jenis penggunaan lahan yang berada di atas bentukl ahan kipas lahar Gunungapi Kelud melalui SIG. Lokasi penelitian difokuskan pada bentuklahan Kipas Lahar Gunungapi Kelud yang beradadi kabupaten Kediri, meliputi wilayah kecamatan Kepung, Puncu, Plosoklaten, Ngancar, dan Wates. Penelitian dilaksanakan pada Mei Juni 2021. Metode yang digunakan adalah metode analisis spasial menggunakan Sistem Informasi Geografis (SIG). Parameter utama yang diamati adalah bentuklahan yang diperoleh dari interpretasi data DEM dan data penggunaan lahan yang diperoleh dari interpretasi citra satelit landsat 8 . Hasil penelitian menunjukkan bahwa bentuk lahan kipas lahar terbentuk dari deposisi lahar dari kejadian erupsi Gunungapi Kelud. Di atas bentuk lahan ini terdapat 6 jenis penggunaan lahan, yaitu penggunaan lahan HTI, perkebunan, pertanian lahan kering, pertanian lahan kering campur semak, permukiman, dan sawah. Dari keenam penggunaan lahan tersebut, penggunaan lahan sawah mendominasi wilayah penelitian, yaitu dengan total luasan $10,136.84$ ha atau $40.00 \%$ dari total luas wilayah penelitian.
\end{abstract}

Kata kunci: Bentang lahan, Gunungapi kelud, Kipas lahar, Penggunaan lahan, SIG

\section{Abstract}

Indonesia is a country that gets the name ring of fire because of the series of volcanoes that pass through it. Each activity will produce a lot of diversity of landforms. The purpose of this study is to analyze the types of land use that are above the Kelud Volcano Lahar Fan landform through GIS. The research location is focused on the Kelud Volcano Lahar Fan landform in Kediri Regency, covering the districts of Kepung, Puncu, Plosoklaten, Ngancar, and Wates. The research was conducted in May - June 2021. The method used is the method of spatial analysis using Geographic Information Systems (GIS). The main parameters observed were landforms obtained from the interpretation of DEM data and land use data obtained from interpretation of Landsat 8 satellite imagery. The results showed that the landforms of Lahar Fan were formed from lahar deposition from the eruption of Kelud Volcano. On this land form, there are 6 types of land use, namely industrial forest land use, plantations, dry land agriculture, dry land mixed bush farming, settlements, and rice fields. Of the six land uses, the use of paddy fields dominates the research area, with a total area of 10,136.84 ha or $40.00 \%$ of the total area of the study area.

Keywords: GIS, Kelud volcano, Lahar fan, Landuse, Landform 
Prosiding Seminar Nasional Pembangunan dan Pendidikan Vokasi Pertanian

Politeknik Pembangunan Pertanian Manokwari, 31 Juli 2021

e ISSN : 2774-1982

DOI : https://doi.org/10.47687/snppvp.v2i1.182

\section{PENDAHULUAN}

Indonesia merupakan negara yang mendapat sebutan ring of fire karena adanya deretan gunung api yang melewatinya. Karena hal ini, menyebabkan Indonesia rawan untuk terjadi aktivitas vulkanik. Aktivitas suatu gunung api ditandai dengan dikeluarkannya material vulkanik dari dapur magma ke permukaan. Material tersebut dapat berupa zat padat, cair, maupun gas. Aktivitas dari suatu gunung api ini mempunyai periode tertentu yang berbeda antara gunung api satu dengan yang lainnya.

Salah satu gunung api yang mempunyai periode letusan yang tergolong singkat antar letusannya adalah gunung api Kelud. Yunita et al. (2008), dalam penelitiannya mengemukakan bahwa gunung api Kelud mempunyai periode letusan rata-rata 20 tahun. Dalam sejarahnya, gunung api Kelud umumnya memiliki letusan yang bersifat eksplosif (De Balizal et al., 2011) dan dalam produk letusannya menghasilkan lahar yang mengancam banyak warga di sekitar lokasi gunung api ini.

Studi tentang identifikasi dan analisis bentuk lahan telah banyak dilakukan. Salah satu metode yang dapat digunakan adalah menggunakan metode analisis spasial menggunakan Sistem Informasi Geografis (SIG) (Utami, et. al 2018; Swardana et al., 2014). SIG merupakan rangkaian kegiatan pengumpulan, penataan, pengolahan, dan penganalisisan data/fakta spasial sehingga diperoleh informasi spasial untuk dapat menjawab atau menyelesaikan suatu masalah dalam ruang muka bumi tertentu (Sajiman, 2006).

Analisis bentuk lahan dapat disandingkan dengan kajian mengenai penggunaan lahan. Penggunaan lahan merupakan hasil aktivitas manusia dalam hal pemanfaatan lahan. Dalam aktivitasnya dalam memanfaatkan dan mengelola lahan, seseorang akan menyesuaikan dengan kondisi lingkungan di sekitarnya. Hal ini berkaitan dengan kemampuan suatu lahan tersebut dalam memenuhi kebutuhan manusianya. Selain itu, penggunaan lahan yang tidak sesuai dengan kemampuan lahan tersebut, dapat menyebabkan degradasi lahan. Untuk itu, lahan perlu dikelola sesuai dengan kemampuannya untuk meminimalisir terjadinya kerusakan lahan. Atas dasar uraian tersebut, maka dilakukan penelitian yang bertujuan untuk menganalisis tipe penggunaan lahan di atas bentuklahan kipas lahar Gunungapi Kelud menggunakan SIG.

Produk letusan suatu gunungapi mempunyai pengaruh dari terbentuknya suatu bentuk lahan di tempat tersebut. Bentuk lahan ini lebih dominan akan terbentuk karena pengaruh dari energi endogen (dalam) dari aktivitas vulkanisme. Salah satu bentuk lahan 
Prosiding Seminar Nasional Pembangunan dan Pendidikan Vokasi Pertanian

Politeknik Pembangunan Pertanian Manokwari, 31 Juli 2021

e ISSN : 2774-1982

DOI : https://doi.org/10.47687/snppvp.v2i1.182

yang terbentuk dari aktivitas vulkanik yang merupakan hasil dari erupsi atau aktivitas gunung api Kelud adalah bentuklahan kipas lahar.

\section{METODE}

Jenis penelitian yang dilakukan adalah penelitian kuantitatif. Wilayah penelitian ini berada dalam wilayah administrasi kabupaten Kediri yang berdekatan lokasinya dengan gunung api Kelud, yaitu masuk pada kecamatan Kepung, Puncu, Plooklaten, Wates, dan Ngancar. Luas daerah penelitian adalah 25,339.13 ha. Lokasi penelitian disajikan pada Gambar 1. Waktu penelitian ini adalah pada Bulan Mei - Juni 2021.

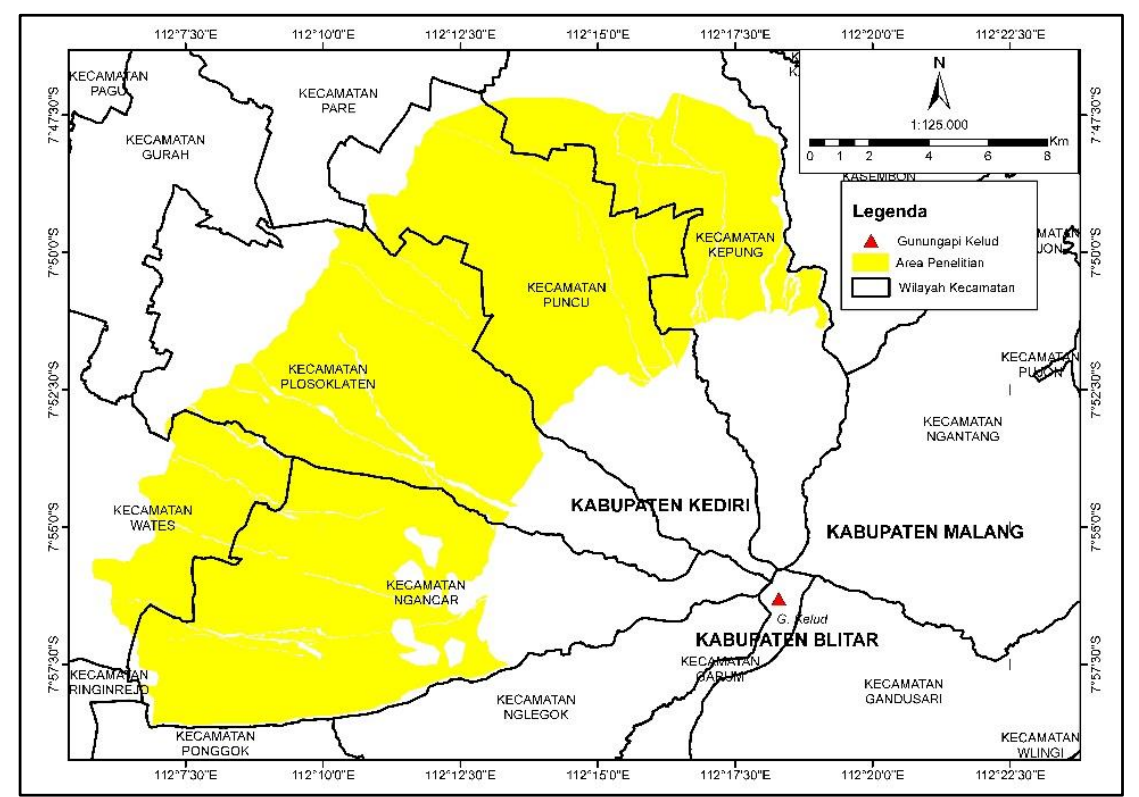

Gambar 1. Peta Lokasi Penelitian

Metode yang digunakan pada penelitian ini adalah analisis spasial menggunakan software Sistem Informasi Geografis (SIG). Data yang digunakan pada penelitian ini adalah data bentuklahan yang diperoleh dari interpretasi data Digital Elevation Model (DEM) pada ketinggian 30 meter dan data penggunaan lahan tahun 2018 yang diperoleh dari interpretasi citra satelit Landsat 8. Kedua data tersebut kemudian ditumpangsusunkan (overlay) untuk memperoleh sebaran penggunaan lahan pada bentuk lahan kipas lahar Gunungapi Kelud. 
Prosiding Seminar Nasional Pembangunan dan Pendidikan Vokasi Pertanian Politeknik Pembangunan Pertanian Manokwari, 31 Juli 2021

e ISSN : 2774-1982

DOI : https://doi.org/10.47687/snppvp.v2i1.182

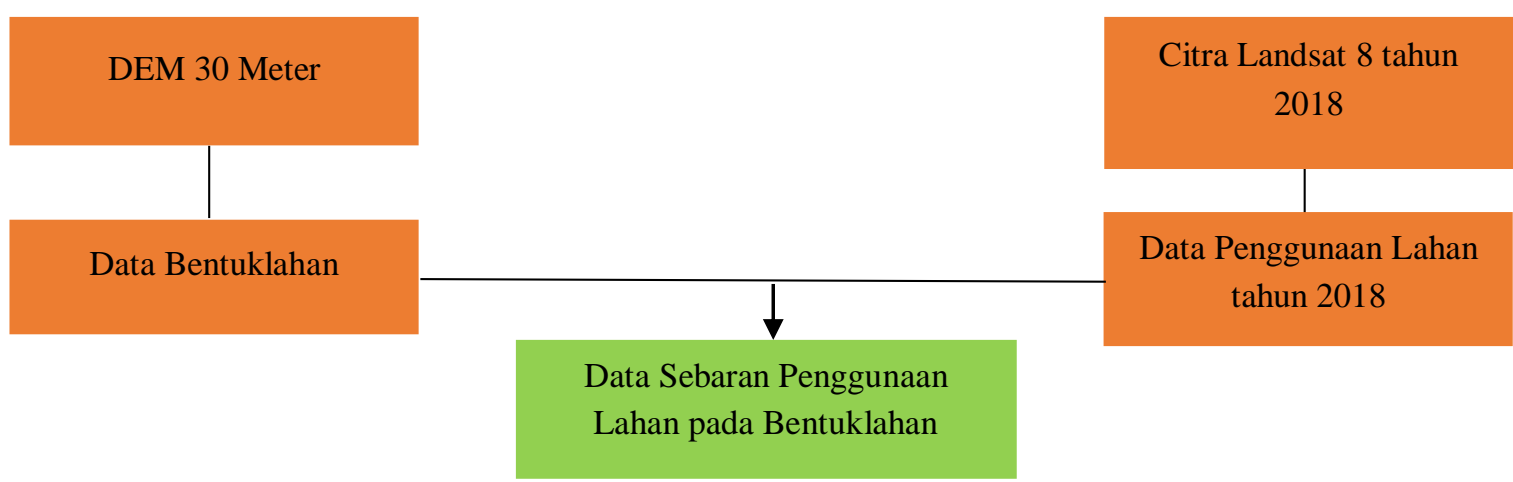

Gambar 2. Diagram Penelitian

\section{HASIL DAN PEMBAHASAN}

\section{Bentuklahan Kipas Lahar Gunungapi Kelud}

Bentuk lahan kipas lahar gunung api Kelud merupakan hasil dari erupsi gunung api yang tersusun material utama berupa lahar. Terbentuknya bentuk lahan ini merupakan penciri dari suatu erupsi gunung api yang salah satunya menghasilkan suatu produk berupa lahar. Lahar adalah produk sekunder dari aktivitas erupsi suatu gunung api.

Lahar didefinisikan sebagai suatu aliran yang berbentuk aliran berkonsentrasi tinggi, yang mana dalam aliran tersebut berisi campuran material berupa batu, kerikil, lumpur, pasir dan air yang berasal dari gunung api. Disebut berkonsentrasi tinggi karena materal lahar yang merupakan aliran berkonsentrasi tinggi (hyperconcentrated) dimana konsentrasi sedimennya berkisar antara 20-60 \% serta mempunyai berat antara 40-80\% (Lavigne et al., 2000).

Lahar dibedakan menjadi 2 berdasarkan waktu terbentuknya, yaitu lahar panas dan lahar dingin/hujan. Lahar panas terjadi saat erupsi gunung api terjadi dimana gunungapi tersebut mengeluarkan material vulkanik dari kawah. Material vulkanik yang sifatnya panas dan bercampur dengan kawah ini kemudian bercampur dan menjadi suatu campuran yang disebut lahar panas. Lahar hujan terjadi saat material vulkanik yang bercampur dengan air hujan.

Bentuk lahan kipas lahar ini terbentuk karena tumpukan material vulkanik baik yang berasal dari tumpukan material vulkanik yang terbawa oleh lahar pada kejadian masa lalu yang kemudian diendapkan pada suatu tempat. Bentuklahan ini disebut juga bentuk lahan deposisional karena terbentuk dari hasil endapan material. Kenampakan bentuk lahan ini ditunjukkan pada Gambar 3. 


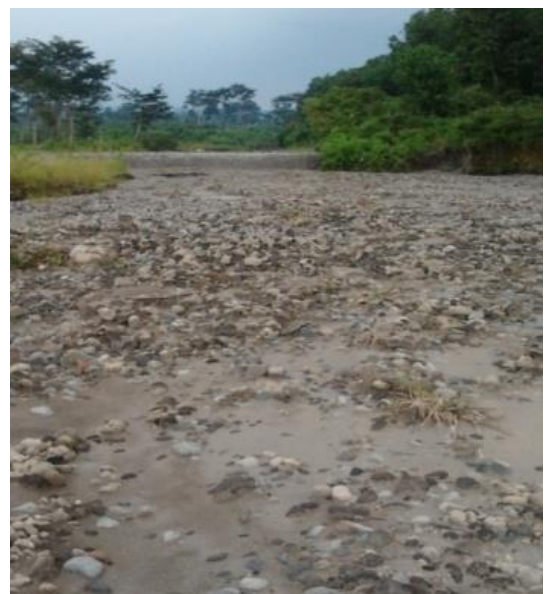

(a)

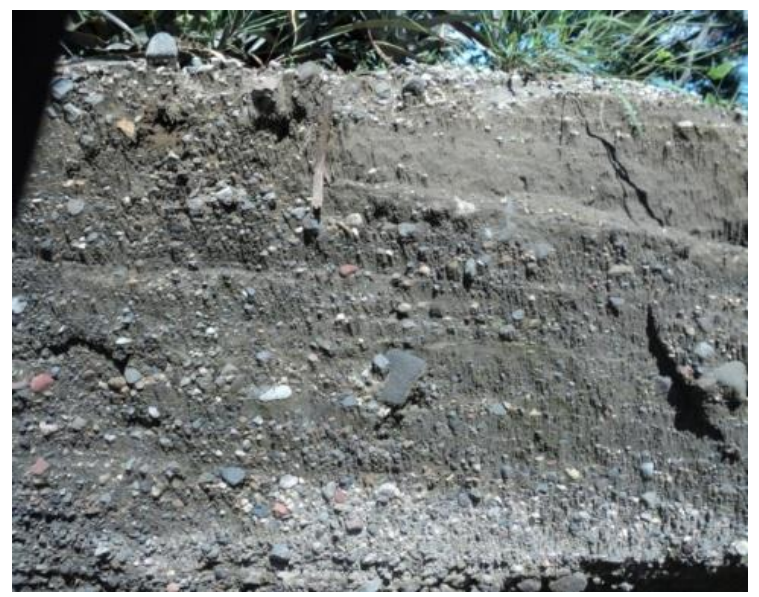

(b)

Gambar 3. Bentuk lahan kipas lahar Gunungapi Kelud, campuran material vulkanik di Sungai Ngobo, Kecamatan Plosoklaten (a) dan singkapan hasil endapan lahar di lahan masyarakat (b)

Seperti dijelaskan di atas, kenampakan kipas lahar ini seperti ditunjukkan pada Gambar 3(a) adalah merupakan campuran material vulkanik yang terdiri dari pasir, debu, kerikil, maupun batu yang diendapkan di suatu lokasi. Endapan lahar ini mempunyai sifat berlapis-lapis karena proses pengendapannya terjadi berulang-ulang pada periode waktu yang lama sehingga dalam setiap endapannya terlihat campuran dari meterial vulkanik yang menyebar di penampang tanah tersebut seperti digambarkan pada Gambar 3(b). Selain itu, dari Gambar 3(b) terlihat bahwa pemilahan material vulkanik yang diendapkan mempunyai pemilahan yang buruk.

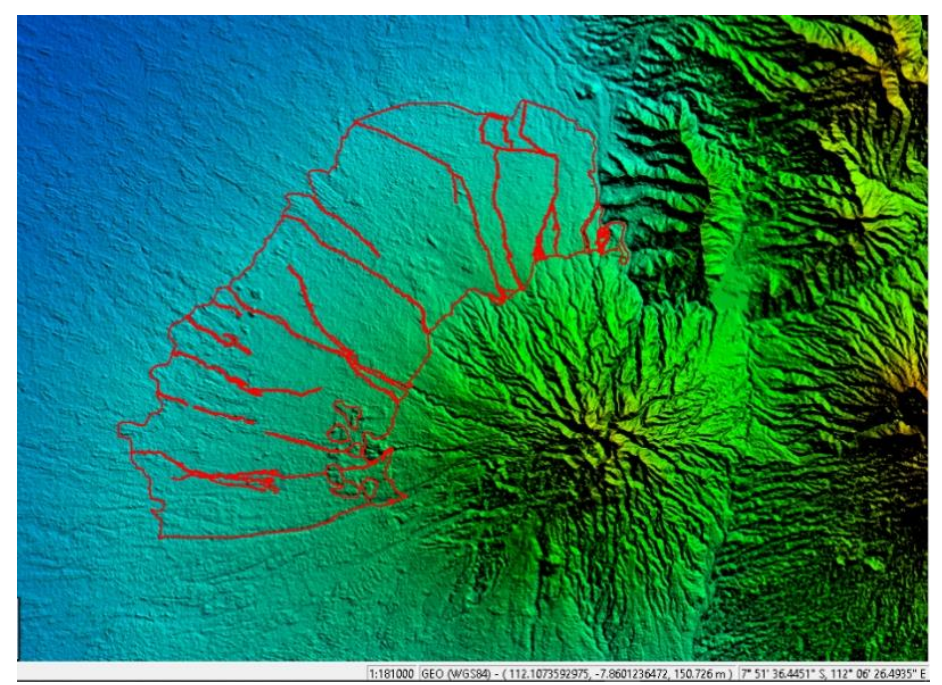

Gambar 4. Kenampakan bentuklahan kipas lahar pada data DEM (daerah yang dibatasi area warna merah) 
Prosiding Seminar Nasional Pembangunan dan Pendidikan Vokasi Pertanian

Politeknik Pembangunan Pertanian Manokwari, 31 Juli 2021

e ISSN : 2774-1982

DOI : https://doi.org/10.47687/snppvp.v2i1.182

Bentuk lahan kipas lahar ini mempunyai umur terbentuk yang lebih muda dari pada bentuk lahan vulkanik lainnya karena sering mendapat tambahan material baru dari hasil endapan. Kenampakan bentuk lahan ini seperti pada Gambar 4 terlihat lebih halus jika dibandingkan dengan daerah sekitarnya. Daerah sekitarnya merupakan bentuk lahan lain yang terbentuk lebih dulu dan telah mengalami proses erosi. Daerah yang terlah tererosi terlihat mempunyai kenampakan yang kasar atau terjal serta terlihat alur sungai atau air yang menunjukkan proses erosi telah terjadi.

\section{Analisis Penggunaan Lahan pada Bentuklahan Kipas Lahar Gunungapi Kelud}

Analisis penggunaan lahan dilakukan dengan interpretasi citra satelit landsat 8 yang diperoleh dari website USGS earth explorer. Pada kegiatan interpretasi ini digunakan citra satelit pada tahun 2018. Berdasarkan hasil interpretasi citra tersebut, diperoleh jenis penggunaan lahan pada bentang lahan kipas kahar gunung api Kelud disajikan pada Tabel 1.

Tabel 1. Sebaran Jenis Penggunaan Lahan dan luasan

\begin{tabular}{|c|c|c|}
\hline Penggunaan Lahan & Luas (ha) & Luas (\%) \\
\hline Hutan Tanaman Industri (HTI) & $3,983.33$ & 15.72 \\
\hline Perkebunan & $6,093.25$ & 24.05 \\
\hline Permukiman & $3,464.23$ & 13.67 \\
\hline Pertanian Lahan Kering (PLK) & 671.68 & 2.65 \\
\hline Pertanian Lahan Kering Campur Semak (PLKCS) & 989.80 & 3.91 \\
\hline Sawah & $10,136.84$ & 40.00 \\
\hline Total & $25,339.13$ & 100.00 \\
\hline
\end{tabular}

Berdasarkan Tabel 1 terlihat bahwa terdapat 6 jenis penggunaan lahan yang terdapat di atas bentuklahan kipas lahar. Penggunaan lahan tersebut antara lain HTI, perkebunan, permukiman, pertanian lahan kering, pertanian lahan kering campur semak dan sawah. Dari keenam jenis penggunaan lahan ini, umumnya penggunaan lahan didominasi oleh jenis penggunaan lahan pertanian. Jenis lahan pertanian yang dimaksud adalah sawah, perkebunan, pertanian lahan kering, dan pertanian lahan kering bercampur semak dengan total luasan $17,891.57$ ha atau $70.61 \%$ dari total luasan keseluruhan.

Penggunaan lahan terbesar yang terdapat di atas bentuklahan ini adalah lahan sawah. Lahan sawah mempunyai luasan 10,136.84 ha atau $40.00 \%$ dari total luasan. Hal ini sejalan dengan mata pencaharian utama masyarakat yang tinggal di kabupaten Kediri secara umum yaitu petani. Selain itu, pada bentuk lahan ini juga terdapat penggunaan lahan permukiman yaitu seluas 3,464.23 ha atau $13.67 \%$. Mengingat daerah ini merupakan bentuk lahan kipas lahar yang terbentuknya dari lahar, maka masyarakat yang bermukim di daerah tersebut 
Prosiding Seminar Nasional Pembangunan dan Pendidikan Vokasi Pertanian Politeknik Pembangunan Pertanian Manokwari, 31 Juli 2021

e ISSN : 2774-1982

DOI : https://doi.org/10.47687/snppvp.v2i1.182

berpotensi untuk terlanda bahaya lahar di kemudian hari. Untuk lebih mendetilkan hasil penelitian, disajikan juga pembagian jenis penggunaan lahan berdasarkan wilayah administrasi dalam hal ini adalah kecamatan seperti terlihat pada Tabel 2.

Tabel 2. Sebaran Jenis Penggunaan Lahan dan luasan per kecamatan

\begin{tabular}{lcccccc}
\hline $\begin{array}{c}\text { Penggunaan } \\
\text { Lahan/Kecamatan }\end{array}$ & Kepung & Ngancar & Plosoklaten & Puncu & Wates & $\begin{array}{c}\text { Total } \\
\text { (ha) }\end{array}$ \\
\hline HTI & 318 & 0 & 500 & 3,165 & 0 & 3,983 \\
Perkebunan & 0 & 2,639 & 3,325 & 0 & 129 & 6,093 \\
Permukiman & 532 & 381 & 823 & 837 & 890 & 3,464 \\
PLK & 447 & 0 & 0 & 225 & 0 & 672 \\
PLKCS & 58 & 91 & 0 & 841 & 0 & 990 \\
Sawah & 2,570 & 3,836 & 1.689 & 838 & 1,204 & 10,137 \\
\hline \multicolumn{1}{c}{ Total (ha) } & $\mathbf{3 , 9 2 5}$ & $\mathbf{6 , 9 4 8}$ & $\mathbf{6 , 3 3 7}$ & $\mathbf{5 , 9 0 5}$ & $\mathbf{2 , 2 2 4}$ & $\mathbf{2 5 , 3 3 9}$ \\
\hline
\end{tabular}

Tabel 2 menjelaskan sebaran jenis penggunaan lahan menurut kecamatan. Terdapat penggunaan lahan yang ada di semua kecamatan, namun ada juga yang hanya terdapat pada beberapa kecamatan saja. Penggunaan lahan yang terdapat di semua kecamatan adalah permukiman dan sawah. Namun, untuk penggunaan lahan HTI, perkebunan, pertanian lahan kering, dan pertanian lahan kering campur semak hanya terdapat pada beberapa kecamatan saja. Secara spasial, sebaran penggunaan lahan disajikan pada Gambar 5.

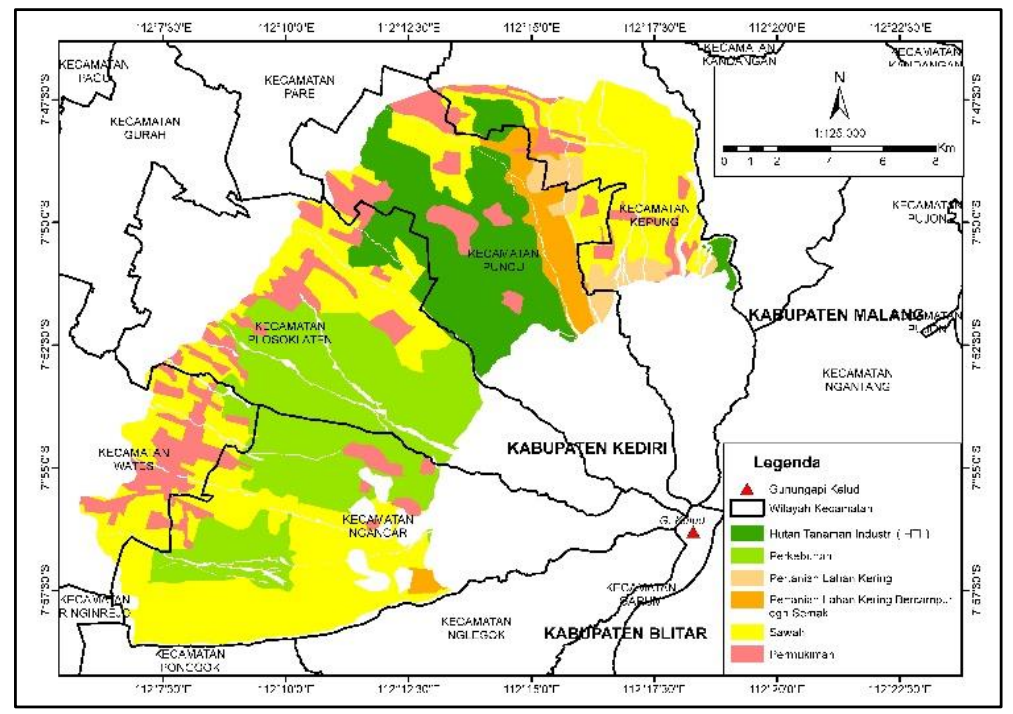

Gambar 5. Peta Penggunaan Lahan

Gambar 5 menunjukkan sebaran jenis-jenis penggunaan lahan yang juga terlihat sesuai dengan pembagian kecamatannya. Posisi penggunaan lahan sawah banyak terdapat pada bagian Selatan dari kecamatan Ngancar dan bagian Utara dari kecamatan Kepung. Penggunaan lahan HTI banyak umumnya mendominasi wilayah kecamatan Puncu dengan 
Prosiding Seminar Nasional Pembangunan dan Pendidikan Vokasi Pertanian Politeknik Pembangunan Pertanian Manokwari, 31 Juli 2021

e ISSN : 2774-1982

DOI : https://doi.org/10.47687/snppvp.v2i1.182

komoditas seperti sengon (Albizia chinensis). Penggunaan lahan perkebunan mendominasi Ngancar dan Plosoklaten. Kondisi tanaman perkebunan yang dibudidayakan di dua kecamatan ini adalah tebu, kopi, kakao, dan nanas. Beberapa tanaman perkebunan yang ada di atas bentuklahan kipas lahar ini ditunjukkan pada Gambar 6. Penggunaan lahan PLK dan PLKCS penyebarannya tidak terlalu sporadis, yaitu terdapat di kecamatan Kepung, Puncu dan Ngancar. Dari keenam penggunaan lahan, yang terlihat menyebar hanya penggunaan lahan permukiman.

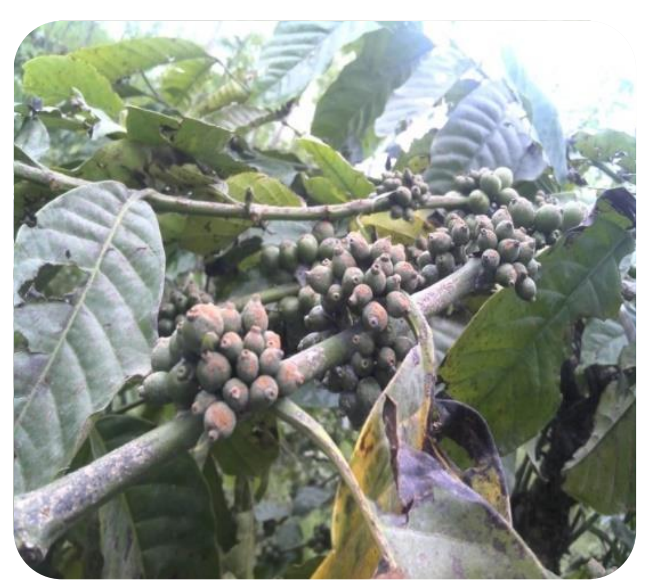

(a)

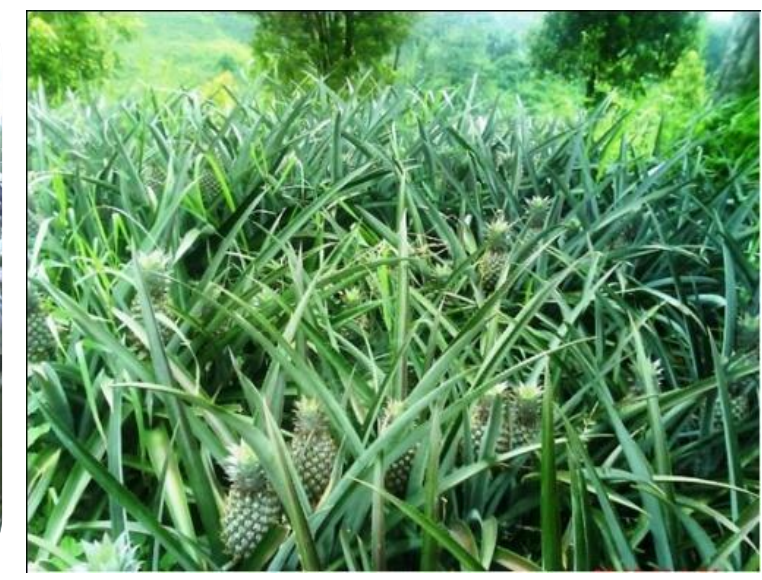

(b)

Gambar 6. Komoditas tanaman perkebunan di atas bentuklahan kipas lahar, tanaman kopi di Desa Spawon, Kecamatan Plosoklaten (a) dan tanaman nanas di Kecamatan Ngancar

(b)

\section{KESIMPULAN DAN SARAN}

Hasil penelitian menunjukkan bahwa terdapat 6 jenis penggunaan lahan di atas bentuklahan kipas lahar gunung api Kelud. Dari jenis penggunaan lahan tersebut, penggunaan lahan sebagai lahan pertanian mendominasi wiayah penelitian. Penggunaan lahan pertanian yang mendominasi wilayah penelitian adalah penggunaan lahan sawah dengan total luasan $10,136.84$ ha atau $40.00 \%$ dari total luas wilayah penelitian.

Saran yang dapat diberikan untuk kedepannya adalah menggunakan data DEM yang lebih akurat lagi (resolusi spasial lebih tinggi). Selain itu, perlu dilakukan penelitian lanjutan terkait perubahan penggunaan lahan di atas bentuk lahan kipas lahar mengingat deposisi lahar masih dapat terjadi sewaktu-waktu.

\section{DAFTAR PUSTAKA}

De Belizal, E., Lavigne, F., Gaillard, J.C., Grancher, D., Pratomo, I., \& Komorowski, J.C. (2011). The 2007 eruption of Kelut volcano (East Java, Indonesia): 
Prosiding Seminar Nasional Pembangunan dan Pendidikan Vokasi Pertanian

Politeknik Pembangunan Pertanian Manokwari, 31 Juli 2021

e ISSN : 2774-1982

DOI : https://doi.org/10.47687/snppvp.v2i1.182

Phenomenology, crisis management and social response. Geomorphology (136). 2012.p.165-175.

Lavigne F, Thouret JC, Voight B, Suwa H, \& Sumaryono A. (2000). Lahars at Merapi Volcano: an overview. Journal of Volcanology and Geothermal Research (100). Tahun 2000. p.423-456.

Sajiman. (2006). Modul Pelatihan sistem informasi Geografis SIG. Bandung:Informatika.

Swardana, A. Boedi, T. \& Barus, B. (2014). Studi Geomorfologi Kabupaten Kediri dan Pemodelan Bahaya Aliran Lahar. Bogor [ID]: Institut Pertanian Bogor (IPB).

Utami, W., Artika, I. G. K., \& Arisanto, A. (2018). Aplikasi Citra Satelit Penginderaan Jauh untuk Percepatan Identifikasi Tanah Terlantar. BHUMI: Jurnal Agraria Dan Pertanahan, 4(1). https://doi.org/10.31292/jb.v4i1.2152.

Yunita, Ratna, E., Fariza, A. \& Sesulihatien, W.T. (2008). Sistem Emergency dan Evaluasi Bencana Gunung Meletus. Studi Kasus: Gunung Api Kelud. Surabaya [ID]: Institut Teknologi Sepuluh Nopember (ITS). 